\title{
PRODUCTION OF ADHESIVE FROM CASSAVA STARCH AND WASTE SYNTHETIC MATERIALS
}

\author{
M.E. Ojewumi ${ }^{1, \bowtie}$, A.O. Ogunbayo ${ }^{2}$, O.O. Olanipekun ${ }^{2}$, E.E. Alagbe ${ }^{1}$, \\ Q.C. Mbonu- ${ }^{1}$, B.M. Durodola ${ }^{3}$ \\ ${ }^{1}$ Department of Chemical Engineering, Covenant University, P.M.B. 1023, \\ Sango Ota, Ogun, Nigeria. \\ ${ }^{2}$ Department of Chemical Engineering, University of Lagos, Akoka, Lagos. Nigeria. \\ ${ }^{3}$ Chemistry Department, Covenant University, P.M.B. 1023, Sango Ota, Ogun, Nigeria. \\ ${ }^{\square}$ Corresponding Author: modupe.ojewumi@covenantuniversity.edu.ng
}

\begin{abstract}
Cassava starch and expanded polystyrene [EP] (Styrofoam) were collected and converted into adhesives. Two starchbased glue were produced from the hydrolysis and dexrination of cassava starch, while the expanded polystyrene was formulated through the dissolution of the solid in benzene. The produced adhesives were tested based on their bonding capacity using four substances: thermoplastic cup, plywood, garden hose and papers. The Expanded polystyrene glue could form bonds with all four materials. The tack/drying time was also recorded during the bonding moments. The rheological properties of the formulated adhesives were studied and it was seen that the glues produced showed properties of a shear-thinning/ pseudo-plastic fluid.
\end{abstract}

Keywords: Adhesive, Glue, Starch, Polystyrene, Hydrolysis, Waste, Rheology

RASĀYAN J. Chem., Vol. 14, No.3, 2021

\section{INTRODUCTION}

The increase in environmental pollution as a result of the use of petroleum-based adhesive and the increase in the demand for adhesive with limited raw material have led to the advent of the industries looking for alternative sources or plant-based materials for the production of new, affordable, cheap and eco-friendly adhesives. ${ }^{1-3}$ The increase in disposal of municipal solid waste and many miscellaneous wastes from the industry in different countries of the world has posed problems to the environment. ${ }^{4}$ Styrofoam usually ends up in incineration or landfills which is a major source of environmental pollution to man. EP can be recycled either chemically or thermally. Chemical techniques however involve the use of hazardous solvents. ${ }^{5,6}$ For example, waste polystyrene takes so many years to biodegrade and is usually resistant to photo-oxidation. ${ }^{7}$ Well, recycled waste materials such as paper, agricultural biomass, cow dung, food waste etc. can be very useful..$^{8-11}$ The elevation in agricultural and kitchen waste has resulted in endangering the life of livestock and plants. Several works have been carried out on different ways by which environmental pollution can be relevant in society by recycling waste to ensure a healthier and cleaner environment. ${ }^{10}$ Researchers have worked on the biodegradation of food waste such as citrus peel and kitchen waste to produce important products such as biogas and ethanol. ${ }^{10,12-18}$

The adhesive is also known as glue, cement, mucilage, sealant, or paste that is capable of joining two or more materials or substances together. Applications range from office to electrical devices, automotive materials to footwear to postage stamps (no-lick). Some products could never have existed if not for adhesive bonding (sealing) e. g. postage stamps. ${ }^{19}$

An adhesive behaves most times as a liquid, in the process of bonding, to easily move over and produce close contact with the adherents. ${ }^{19}$ Through the development of intermolecular forces, they form surface attachment. ${ }^{20}$ Adhesives are chosen for their bonding property and holding ability. ${ }^{20-21}$ Thermosetting acrylic, epoxy and urethane systems are common structural adhesives. ${ }^{21}$ Cassava (Manihot esculenta Crantz) is a long taproot with a fleshy soft outer body. It is a vegetative propagated shrub with rough and 
brown outside and it is mainly cultivated for its starchy roots (tuberous), which has about 74 to $85 \%$ of the total dry weight. ${ }^{22-24}$ Cassava is one of the major staple food in Africa. ${ }^{23}$ So many research works have been carried out on starch-based materials by so many institutions including corporate laboratories to improve the mechanical properties of such materials for numerous commercial application purposes. ${ }^{22}$

Reported Styrofoam to be tough and with tightly packed materials and with density ranging from 11 to $32 \mathrm{~kg} / \mathrm{m}^{3}$. This material is popularly used in various applications because of the characteristics it possesses, such as effective thermal insulation, lightweight, durability, good moisture resistance, low thermal conductivity and acoustic absorption. It can be used in building constructions as important material for structural insulated panels. ${ }^{25}$ Styrofoam is commonly used for packaging materials and insulation. Many industries use it because of its dimensional stability, versatility, clean nature and low cost. ${ }^{26-28}$

This research work aimed at producing adhesive from cassava starch and waste materials such as Styrofoam [EP]. This product is eco-friendly, economical and readily available.

\section{Material and Methods}

Cassava Starch

Manihot Exculenta (specie of cassava) was acquired from a nearby farm settlement in Ogun state. The raw tubers were processed into starch using methods. ${ }^{28-33}$

\section{Expanded Polystyrene}

Expanded polystyrene was obtained from the waste packages of electronics around the staff residential Quarters.

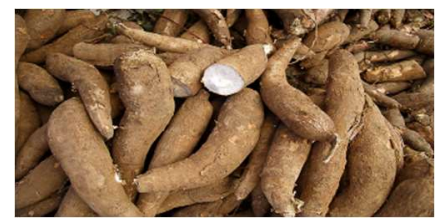

Plate-1: Cassava Tubers

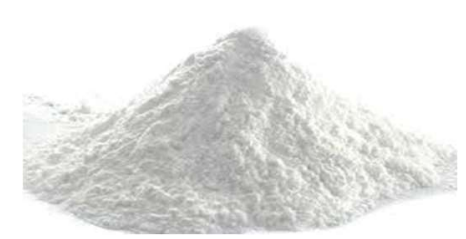

Plate-2: Cassava Starch

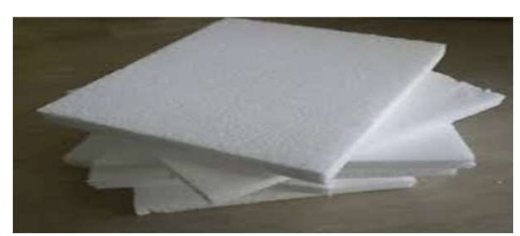

Plate-3: Expanded Polystyrene

\section{General Procedure}

\section{Production of Adhesives from Cassava Starch}

The cassava starch was collected after processing and dried with the use of an oven (Vision Scientific (Japan) model-LDO-201-E) at a temperature of $50^{\circ} \mathrm{C}$ for eight hours to remove the amount of moisture previously present in the starch. The fine starch was then stored in an airtight vessel to avoid contamination and moisture.

Two types of adhesives were produced from cassava starch namely:

$$
\text { (i) Hydrolysed starch and }
$$

Dextrin Starch additives.

\section{Production of Hydrolysed Starch Adhesive}

30 grams of processed cassava starch was weighed into a $200 \mathrm{ml}$ beaker and was thoroughly dissolved with $80 \mathrm{ml}$ of water, after which 2 grams of sodium hydroxide pellets were weighed and dropped into the beaker. The solution was heated with a magnetic stirrer placed inside it on a hot plate at the gelatinization temperature of $70^{\circ} \mathrm{C}$ until the glue was formed after which $8 \mathrm{~mL}$ of hydrochloric acid was added to neutralize the material, glycerol was added as well as formaldehyde as a preservative to the glue.

\section{Dextrin Starch Adhesives}

40 grams of cassava starch was heated with $5 \mathrm{ml}$ of hydrochloric acid at $110^{\circ} \mathrm{C}$ using a hot plate for 45 minutes. The mixture was diluted in $150 \mathrm{ml}$ distilled water inside a beaker, the solution was heated and continuously stirred with the hot plate magnetic stirring equipment at the gelatinization temperature $70^{\circ} \mathrm{C}$ until the resultant glue was formed. $2 \mathrm{M}$ of caustic soda was added to enhance viscosity and to neutralize the glue, borax was added to improve the glue's tacking properties and formaldehyde was used as a preservative. 
RASĀYAN J. Chem.

Vol. 14 | No. 3 |1835-1844| July - September | 2021

\section{Production of Adhesives from the Expanded Polystyrene [Styrofoam]}

Collected Styrofoam was sorted to be free of impurities and crushed into fine sizes. $100 \mathrm{ml}$ of benzene was collected using a burette in a $500 \mathrm{ml}$ glass beaker, and slowly added to $125 \mathrm{~g}$ of crushed Styrofoam, it was then stirred continuously, and allowed to stand for 5 minutes. A thick and coagulated substance was seen after few minutes as the resultant glue produced. ${ }^{6,10}$

\section{Physical Characterizations of the Produced Adhesives}

To determine the assured quality of the produced glue, the adhesives were characterized physically by analyzing the $\mathrm{pH}$ value, density, ash and moisture content of the adhesive and comparing them with industry standards. All outcomes were the mean of repeated analysis.

\section{Moisture Content}

$10 \mathrm{ml}$ of formulated adhesive was measured out in a porcelain crucible and was dried in a drying oven at a temperature of $105^{\circ} \mathrm{C}$ for 4 hours, after which the adhesive was allowed to cool in the desiccator for 8 hours. The mass of the sample was measured. The moisture content was obtained with equation. ${ }^{31-33}$

$$
\text { Moisture Content (\%) = [ Weight of Moisture in Adhesive / Weight of Adhesives before Drying] X } 100
$$

\section{Determination of $\mathbf{p H}$}

The $\mathrm{pH}$ value was determined with the aid of the digital $\mathrm{pH}$ meter (Jenway model) using the reported methods. ${ }^{32-33}$

\section{Determination of Density}

The density of the produced adhesives was determined using a density bottle with a known weight, and the volume of the adhesive put into the bottle was measured the density was then calculated and recorded.

\section{Determination of Ash Content}

$10 \mathrm{~g}$ of the formulated adhesive was measured out in a porcelain crucible and was heated in a furnace at $555^{\circ} \mathrm{C}$ temperature, after which the adhesive was allowed to cool at room temperature inside a desiccator then the mass of the sample was measured. ${ }^{31-33}$

Ash Content $(\%)=[$ Mass of Dry Glue Sample / Mass of Original Glue Sample] X 100

\section{Rheological Properties of the Adhesives Produced Determination of Viscosity}

The Viscosity contour of the adhesives was determined using a viscometer (LvDv I+, Brookfield, USA) with the spindle set ranging from $10 \mathrm{rpm}$ to $100 \mathrm{rpm}$ following the technique proposed, ${ }^{34,35}$ to establish the characteristics of the fluid.

\section{Adhesion to Substrate}

The formulated adhesives were tested based on their resourcefulness in the adhesion of different materials using the following materials; Thermoplastic cups, Plywood, Paper and Rubber Hose.

\section{Curing Time of the Adhesive}

The time is taken for the bond formation to occur at the various substrates using a stopwatch.

\section{Peel Strength Testing of Adhesives}

The peel strength was determined by using the Thwing-Albert QC-3A Universal testing machine according to the ASTM D 1876, commonly called the T-peel test. The bonded test panels are $50 \mathrm{~mm}$ by $30 \mathrm{~mm}$ test specimens. These are then bonded for approximately $30 \mathrm{~mm}$ of their length. The universal testing machine was then used to apply a load at a constant crosshead speed of $12.50 \mathrm{~mm} / \mathrm{min}$. The average load in kilo Newton per square meter of specimen required to separate the adherents is determined for the first $10 \mathrm{~mm}$ of cleavage/peel after the initial peak. The peel strength was calculated as: 
RASĀYAN J. Chem.

Vol. 14 | No. 3 |1835-1844| July - September | 2021

Peel Strength $=[$ Force at Peak / Area of the Test Piece Subjected to Cleavage $]$ X 100

With the area calculated as $30 \mathrm{~mm} \times 10 \mathrm{~mm}=300 \mathrm{~mm}^{2}$

\section{Tensile Strength Testing of Adhesives}

Samples were cut into $25.4 \mathrm{~mm}$ width and $80 \mathrm{~mm}$ length plus overlap length which was maintained at 30mm. ASTM D2559-Standard Specification method for Adhesives of Bonded Structural Wood Products was used. The wood lap joint specimen was fixed until the adhesive was fully cured within room temperature. The average load in kiloNewton per square meter of specimen required to separate the adherents is then determined using the universal testing machine.

The tensile strength was calculated as:

Tensile Strength $=[$ Force at Peak / Area of the Piece Subjected to Test $]$ X 100

\section{RESULTS AND DISCUSSION}

\section{pH}

The $\mathrm{pH}$ value of the adhesives indicated how basic or acidic the glue is. The $\mathrm{pH}$ value plays an important role in the manufacture of adhesives as it ensures the production of adhesives with consistent well-defined properties, it produces adhesives at optimal cost, to prevent health problems to customers and ensure the adhesive is up to regulatory requirements. The $\mathrm{pH}$ values of the three different types of glue were measured and compared to that of commercial glue. Hydrolyzed starch glue showed a $\mathrm{pH}$ of 9.2 from Table-1, this is because one of the main components of this glue is caustic soda a basic solution hence the glue altogether was basic. Sodium hydroxide can neutralize adhesives ${ }^{35}$, and an increase in the quantity of this compound would make the adhesive increase in alkalinity. ${ }^{36}$ The Dextrin starch from table 1 had a $\mathrm{pH}$ value of 8.31 ; this was expected because for dexrination to take place the starch has to be roasted with an acid, and the viscosity was enhanced using two basic compounds Sodium tetraborate and caustic soda, a similar result was obtained in the reported research work ${ }^{35,37}$, where an increase in sodium tetraborate led to an increase in the of value in the negative logarithmic scale. The Expanded polystyrene-based glue, a $\mathrm{pH}$ value of 6.5 was recorded; benzene being an organic solvent has different values of $\mathrm{pH}$ at different states ${ }^{37}$, however, the commercial glue showed a $\mathrm{pH}$ value close to the neutral level on the logarithmic scale.

\section{Density}

The density of an adhesive indicates the degree of firmness of the glue; it is an important physical property as it shows the thickness and volume of the glue being used for substrate bonding. Table- 1 shows the different values of densities obtained from the different adhesives produced, about the cassava starch-based glue using hydrochloric acid modifiers which has a density ranging from $1.026-1.126 \mathrm{~g} / \mathrm{cm}^{3}$ according to reported reserech ${ }^{37}$, this range of value differs from that of the dextrin glue in this study because different molarity of hydrochloric acid was used, the density obtained from this study was $1.13 \mathrm{~g} / \mathrm{cm}^{3}$ this is so because adhesives become thicker with a higher molecular weight ${ }^{36}$, the density of both the hydrolyzed starch-based glue and the expanded polystyrene based glue are $1.09 \mathrm{~g} / \mathrm{cm}^{3}$ and $1.01 \mathrm{~g} / \mathrm{cm}^{3}$ respectively. Hence, this shows that the thickness of the dextrin starch-based glue would be highest during bonding moments followed by the hydrolyzed starch glue then the expanded polystyrene-based glue. The thickness of the glue doesn't affect the bonding capability of the adhesives but the drying time is generally affected, as the higher thickness would lead to a longer drying time.

\section{Moisture Content}

The moisture content of the adhesive, if high could affect the texture of the glue, the shelf life; it could also lead to growth in microbes. To investigate this, the moisture content was determined for the three adhesives produced and it was then compared that of the standard glue, it was concluded that the expanded polystyrene based glue showed closer proximity (than the others) to that of the standard glue, the value being $27 \%$ of moisture, the standard glue was $15 \%$ of moisture. The dextrin starch glue had the highest amount of water content showing $58 \%$ of moisture while the hydrolyzed starch glue was $30 \%$ of moisture calculated; these values are so because starch adhesives are water-based adhesives, while synthetic adhesives are more solvent-based. The starch glues were formulated with water, the dextrin containing $70 \mathrm{ml}$ more than the 
hydrolyzed while the EP glue was formulated with an organic solvent; hence the moisture content is the amount of water in glue. ${ }^{26}$

\section{Ash Content}

The ash content of the adhesives shows the percentage of inorganic compounds in the polymers. ${ }^{30}$ It is done to determine the quality of the adhesives as it sometimes depends on the concentration and types of minerals it contains. The ash content also gives an intermediate study of the toxicology of the adhesives from a limited point of view. Table-1 shows that the expanded polystyrene adhesive has the least number of inorganic components present in the glue, with a value of $0.28 \%$ The dextrin-based glue has up to $6.3 \%$ of inorganic components while the hydrolyzed glue possesses $4.28 \%$ of inorganic compounds, this is so because the expanded polystyrene is composed of organic material, unlike the starch-based glue that has been cross-linked with an inorganic compound like caustic soda and hydrochloric acid.

Also, the denser the glue, the more ash is obtained, ${ }^{32}$ this is true in this study as the dextrin starch was the densest glue and the one with the highest ash content value.

The rheology of the adhesives shows the ability of the adhesives to flow; it also shows the viscoelastic properties. The study of rheology of the produced adhesives was carried out to establish the type of fluid the adhesive produced was and to determine its similarities with other adhesives. Adhesive viscosity has a significant part in how strong bonds are formed ${ }^{36}$, tensile strength and other mechanical characteristics in the complex materials. Figures- 1 and 2 show the viscosity obtained by the starch-based adhesives as well as the expanded polystyrene-based adhesives respectively. It was observed that viscosity of the fluids drastically decreases with an increasing speed of the rotor, then later decreases at an almost uniform rate with an increasing rotor speed ${ }^{35}$, it was similarly stated that this kind of behavioral pattern is observed in pseudo-plastic fluids, also known as shear-thinning fluids.

It was also observed that dextrin starch adhesive had the highest viscosity level, at the rotor speed 10rpm the viscosity was seen to be at $13900 \mathrm{cP}$ while the hydrolyzed starch viscosity at $10 \mathrm{rpm}$ was $4000 \mathrm{cP}$ and Styrofoam based glue at $10 \mathrm{rpm}$ recorded a viscosity of $500 \mathrm{cP}$. The viscosity of the glue is a very important parameter when it comes to picking the most suitable adhesive because it may be difficult to apply very viscous adhesives on the substrates.

Table-1: Physical Characterization of the produced Adhesives

\begin{tabular}{c|c|c|c|c}
\hline & $\begin{array}{c}\text { Hydrolyzed } \\
\text { Starch } \\
\text { Adhesive }\end{array}$ & $\begin{array}{c}\text { Dextrin } \\
\text { Starch } \\
\text { Adhesive }\end{array}$ & $\begin{array}{c}\text { Expanded } \\
\text { Polystyrene } \\
\text { Adhesive }\end{array}$ & $\begin{array}{c}\text { Commercial } \\
\text { Adhesive }\end{array}$ \\
\hline Ash Content & $4.28 \%$ & $6.30 \%$ & $0.28 \%$ & $3.99 \%$ \\
\hline Moisture Content & $31 \%$ & $58 \%$ & $28 \%$ & $32 \%$ \\
\hline Density at $25^{\circ} \mathrm{C}$ & $1.09 \mathrm{~g} / \mathrm{cm}^{3}$ & $1.13 \mathrm{~g} / \mathrm{cm}^{3}$ & $1.01 \mathrm{~g} / \mathrm{cm}^{3}$ & $0.65 \mathrm{~g} / \mathrm{cm}^{3}$ \\
\hline $\mathrm{pH}$ Value & 9.21 & 8.31 & 6.59 & 6.81 \\
\hline Viscosity at $25^{\circ} \mathrm{C}$ & $2590 \mathrm{cP}$ & $3620 \mathrm{Cp}$ & $3900 \mathrm{cP}$ & $2660 \mathrm{cP}$ \\
\hline Softening Temperature & 80 & $100^{\circ} \mathrm{C}$ & $80^{\circ} \mathrm{C}$ & $100^{\circ} \mathrm{C}$ \\
\hline Tensile Strength & $35.87 \mathrm{KPa}$ & $17.94 \mathrm{KPa}$ & $34.1 \mathrm{KPa}$ & $36.9 \mathrm{KPa}$ \\
\hline Peel strength & $19.98 \mathrm{KPa}$ & $12.15 \mathrm{KPa}$ & $22.920 \mathrm{KPa}$ & $20.22 \mathrm{KPa}$ \\
\hline Colour & Brownish & White & Greyish & White \\
\hline Odor & Odorless & Odorless & Odorless & Odorless \\
\hline Base Polymer & Starch & Starch & Polystyrene & Starch \\
\hline
\end{tabular}

\section{Peel Strength of Produced Adhesives}

Table-2 was derived from the investigations of the peel strength of the starch-based glue and the EP-based glue. The peel strength of glue determines the force required to slowly 'peel off' two bonded materials at a constant velocity. ${ }^{37}$

The results attained were plotted in Fig.-3, the force increased steadily, this region is referred to as the modulus of elasticity, where the adhesive stiffness is measured, after which failure starts to occur until the adhesive bond gives way. ${ }^{37}$ The force at which the materials fail tends to fluctuate to average values as the test continues this can be seen in Table- 2 . 
RASĀYAN J. Chem.

Vol. 14 | No. 3 |1835-1844| July - September | 2021

Rheological Properties of the Adhesives Produced

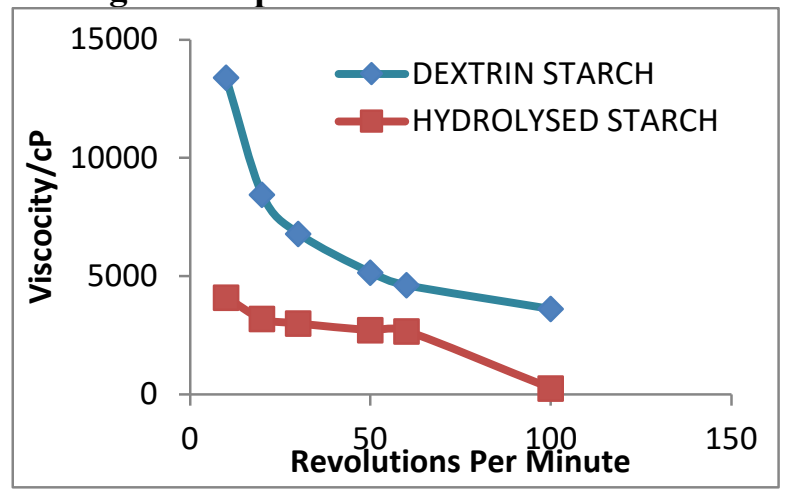

Fig.-1: Viscosity Profile of the Starch-based Adhesive against the Revolutions per Minute Value

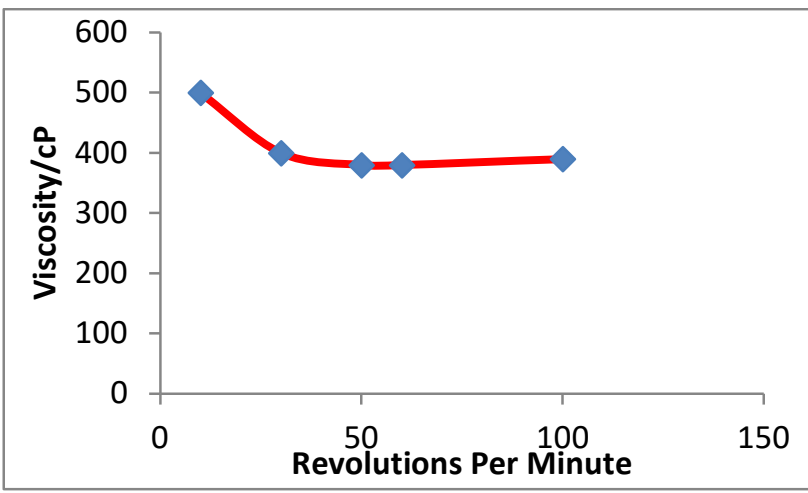

Fig.-2: Viscosity Profile of the Expanded Polystyrene Adhesive against the Revolutions per Minute value

Table-2: Peel Strength of Various Adhesives produced

\begin{tabular}{c|c|c|c|c|c|c|c|c}
\hline S. No. & \multicolumn{4}{|c|}{ Force at Peak (N) } & \multicolumn{4}{c}{ Peel strength (KPa) } \\
\hline & EPG & HYG & DXG & COMM & EPG & HYG & DXG & COMM \\
\hline 1 & 6.850 & 6.030 & 3.610 & 7.330 & 22.830 & 20.100 & 12.030 & 23.650 \\
\hline 2 & 6.790 & 5.900 & 3.690 & 7.370 & 22.630 & 19.670 & 12.300 & 24.100 \\
\hline 3 & 6.990 & 6.050 & 3.640 & 7.660 & 23.300 & 20.170 & 12.130 & 24.220 \\
\hline Mean & 6.880 & 5.990 & 3.650 & 7.380 & 22.920 & 19.980 & 12.150 & 23.870 \\
\hline
\end{tabular}

COMM - Commercial glue (adhesive)

EPG - Expanded polystyrene glue (Adhesive)

DXG - Dextrin glue (Adhesive)

HYG - Hydrolysed glue (Adhesive)

STG - Starch glue (Adhesive)

As shown in Fig.-3, the peel strength result for dextrin glue, the peak force required to peel the bonded material was $3.64 \mathrm{~N}$, and its corresponding peel strength was calculated to be $12.15 \mathrm{KPa}$ at this strength the displacement between the two bonded materials is about $4 \mathrm{~mm}$ apart. The same can be said for the hydrolyzed glue, the peak force to peel of the adherents is shown to be $5.99 \mathrm{~N}$ at this force applied the substrates are also $4 \mathrm{~mm}$ apart, whereas the peel strength is calculated to be $19.980 \mathrm{KPa}$. Therefore, it can be said that the hydrolyzed glue requires a greater force to be able to peel two substrates when compared to the dextrin starch. In Expanded polystyrene the peak force recorded was $6.88 \mathrm{~N}$ and the corresponding distance at which the bonded materials was $6 \mathrm{~mm}$ apart with $22.920 \mathrm{KPa}$ as its peel strength. These results are in agreement ${ }^{22}$, which recorded that thermoplastic adhesive form very strong and lasting bonds at normal temperatures. From Table-2, the results were obtained in triplicates to ensure maximum accuracy for determining the adhesives with the highest peel strength.

\section{Tensile Strength of Produced Adhesives}

The tensile strength was carried out to determine the force required to 'pull apart' the bonded substrates and to measure the adhesive bond's response to the applied stress. This differs from the peel test, as the act of peeling and pulling are different but the two tests focus on bringing out the glue that provides the strongest bonds.

The modulus of elasticity was also projected in Fig.-4. In the first stage of the test when the force applied was withdrawn the adhesive bond remains intact in this stage. The following stage is called the yield point, this is the point where the bond starts to deform, ${ }^{35-37}$ and after this stage rapid deformation of the adhesive bond takes place. As shown in Fig.-4, the tensile strength result for dextrin glue, the peak force required to pull out the bonded material was $5.383 \mathrm{~N}$, and its corresponding tensile strength was calculated to be $17.940 \mathrm{KPa}$ at this strength the displacement between the two bonded materials are about $1.3 \mathrm{~mm}$ apart. The same can be said for the hydrolyzed glue, the peak force to pull out the adherents is shown to be $10.710 \mathrm{~N}$ at this force applied the substrates are also $1.3 \mathrm{~mm}$ apart, whereas the tensile strength is calculated to be 
35.870KPa. Consequently, it can be said that the hydrolyzed glue requires a greater force to be able to pull out two substrates when compared to the dextrin starch. Additionally, in the synthetic Expanded Styrofoam starch in same Fig.-4, where the peak force recorded is $102.370 \mathrm{~N}$ and corresponding distance at which the bonded material peel strength is said to be $1.3 \mathrm{~mm}$ and its tensile strength is calculated to give $341.11 \mathrm{KPa}$. This further corroborates the statement, ${ }^{37}$ that synthetic thermoplastic adhesives form durable and stronger bonds at room temperature.

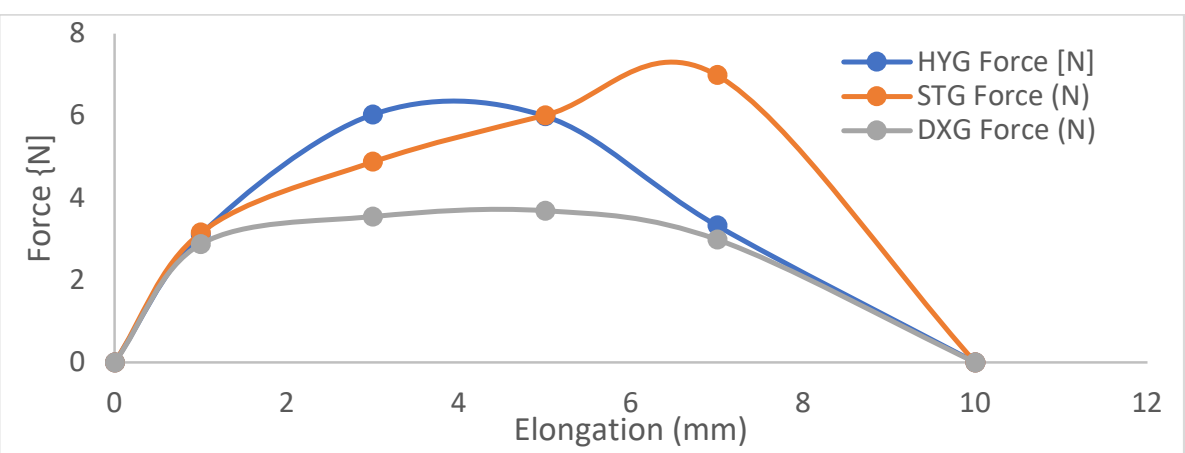

Fig.-3: Force Applied to produced Adhesive and its Elongation in the Peel Strength Profile

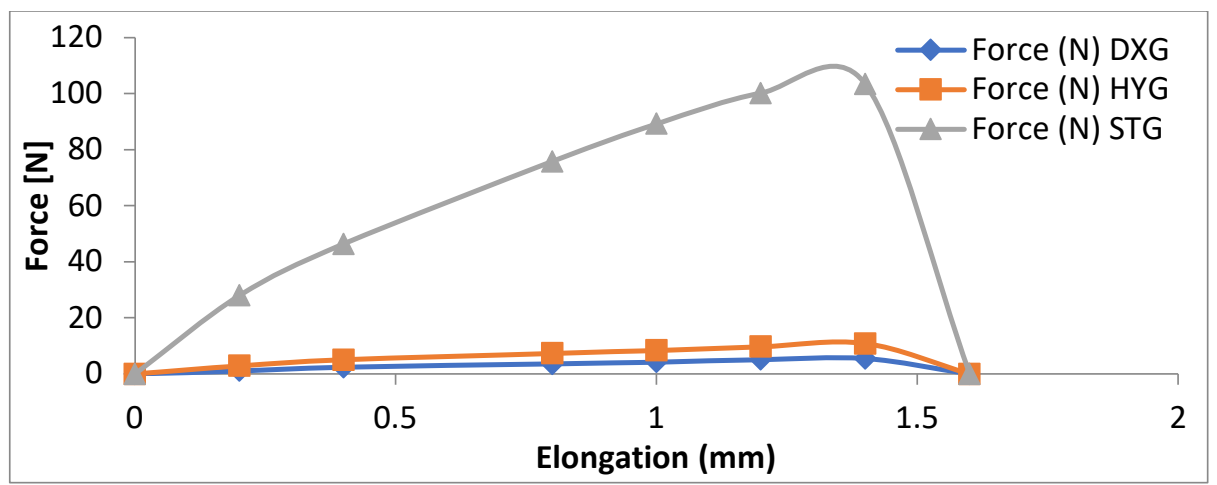

Fig.-4: Force Applied produced Adhesive and its Elongation in the Tensile Strength Profile

Table-3: Tensile Strength of Various Adhesive

\begin{tabular}{c|c|c|c|c|c|c|c|c}
\hline S. No. & \multicolumn{4}{|c|}{ Force at Peak $(\mathrm{N})$} & \multicolumn{4}{c}{ Tensile strength $\left(\mathrm{N} / \mathrm{mm}^{2}\right)$} \\
\hline & EPG & HYG & DXG & COMM & EPG & HYG & DXG & COMM \\
\hline 1 & 102.10 & 10.620 & 5.30 & & 34.000 & 35.400 & 17.670 & 38.500 \\
\hline 2 & 101.50 & 10.860 & 5.41 & & 34.330 & 36.200 & 18.030 & 38.550 \\
\hline 3 & 103.50 & 10.800 & 5.44 & & 35.000 & 36.000 & 18.130 & 38.320 \\
\hline Mean & 102.370 & 10.710 & 5.383 & & 34.11 & 35.870 & 17.940 & \\
\hline
\end{tabular}

COMM - Commercial glue (adhesive); EPG - Expanded polystyrene glue (Adhesive), DXG - Dextrin glue (Adhesive), HYG - Hydrolysed glue (Adhesive)

As in the peel test, the tensile test results from Table-3, were in triplicates to ensure maximum accuracy for determining the adhesives with the highest tensile strength.

\section{Adhesion to Substrate}

The different adhesives produced were tested for their adhesion capabilities to different substrates to identify the glue, which has the highest versatility. From Table- 4 , it can be seen that the Styrofoam glue showed the highest adhesion power as it was able to bond all five of the materials used for the investigation while the starch-based adhesives were only able to bond papers and mend books, they also showed adhesion ability in bottle labeling and the use of cardboard papers. 
RASĀYAN J. Chem.

Vol. 14 | No. 3 |1835-1844| July - September | 2021

Table-4: Application of Produced Adhesives to Different Materials

\begin{tabular}{c|c|c|c|c|c}
\hline & Thermoplastic & Bookbinding & Paper bond & Garden hose & Plywood \\
\hline Dextrin Starch Glue & $\mathrm{X}$ & $\sqrt{ }$ & $\sqrt{ }$ & $\mathrm{X}$ & $\mathrm{X}$ \\
\hline Hydrolysed Starch Glue & $\mathrm{X}$ & $\sqrt{ }$ & $\sqrt{ }$ & $\mathrm{X}$ & $\mathrm{X}$ \\
\hline Styrofoam based glue & $\sqrt{ }$ & $\sqrt{ }$ & $\sqrt{ }$ & $\sqrt{ }$ & $\sqrt{ }$ \\
\hline
\end{tabular}

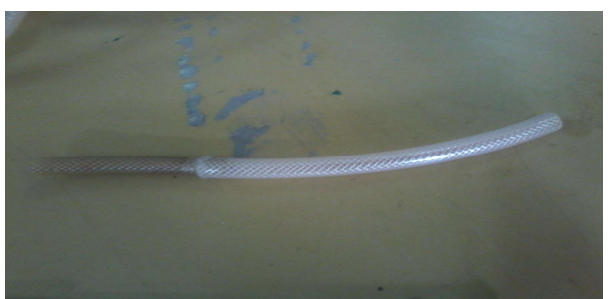

Plate-A: Bonded Garden Hose

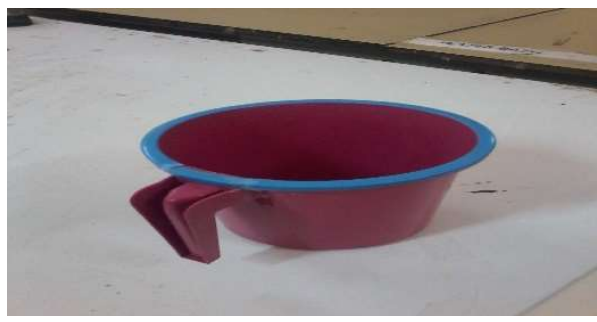

Plate-C: Bonded Thermoplastic Cup

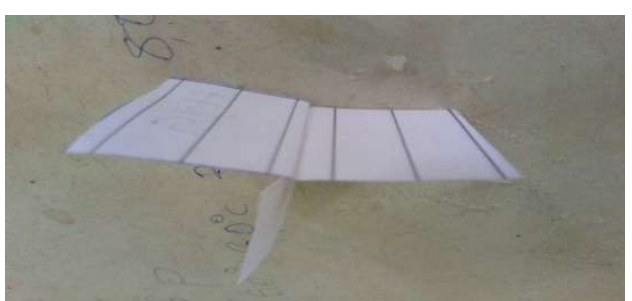

Plate-B: Bonded Paper

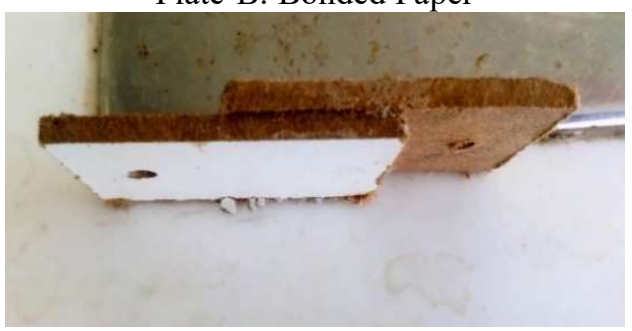

Plate-D: Bonded Plywood

Tacking /Drying Time of Adhesive

Fig.-4: Applications of the produced adhesives

The drying time (curing or tack time) of the adhesives were also investigated, and from Table-5, it was observed that the expanded polystyrene based glue had the shortest curing time for all the materials used, followed by the Hydrolysed starch glue then the dextrin starch glue was seen have had the slowest curing time. This result can be linked to the thickness of the adhesive; the dextrin glue was the thickest, while the expanded polystyrene glue was the least amongst the three, as shown in Table-5.

Table-5: Time Taken for Adhesive to Tack (Minutes)

\begin{tabular}{c|c|c|c|c|c}
\hline & Thermoplastic & Book Binding & Paper Bond & Garden Hose & Plywood \\
\hline Dextrin Starch Glue & - & 8 & 2.5 & - & - \\
\hline Hydrolysed Starch Glue & - & 5 & 1 & - & - \\
\hline Styrofoam based Glue & 25 & 1.2 & 0.5 & 5 & 18 \\
\hline Commercial Glue & 20 & & & & \\
\hline
\end{tabular}

When the viscosity is too high the adhesive has difficulties in the formation of a bond due to the obstruction of current necessary to from such bond. ${ }^{37}$ Dextrin glue was shown to have the highest viscosity.

\section{CONCLUSION}

The adhesives formulated showed the characteristics of a pseudoplastic fluid also known as a shear-thinning fluid, which is the general characteristic behavior of polymer solutions. The adhesives produced were all non-reactive, pressure-sensitive and drying adhesives. The adhesion bond formed followed the wettability theory of the adhesion theories. The Adhesive with the strongest binding power was seen to be the expanded polystyrene-based adhesive as it was able to bind thermoplastics, plywood, papers, garden hose and for the use of book mending while the starch-based adhesives were used for the paper bonds and bottle labeling. The most suitable adhesive formulated was identified to be the Styrofoam-based adhesive.

\section{ACKNOWLEDGEMENT}

The authors appreciate the sponsorship of Covenant University, Ota, Ogun State. 
RASĀYAN J. Chem.

Vol. 14 | No. 3 |1835-1844| July - September | 2021

\section{REFERENCES}

1. D. Araújo, V. D. Alves, J. Campos, I. Coelhoso, C. Sevrin, C. Grandfils, F. Freitas, and M. A. Reis, International Journal of Biological Macromolecules, 92, 383(2016), https://doi.org/10.1016/j.ijbiomac.2016.07.035

2. A. P. Haag, R. M. Maier, J. Combie, and G. G. Geesey, International Journal of Adhesion and Adhesives, 24(6), 495(2004), https://doi.org/10.1016/j.ijadhadh.2004.01.004

3. H. Xu, J. Luo, Q. Gao, S. Zhang, and J. Li, BioResources, 9(3), 4667(2014).

4. V. Ferrándiz-Mas, T. Bond, E. García-Alcocel, and C. R. Cheeseman, Construction and Building Materials, I(61), 285(2014), https://doi.org/10.1016/j.conbuildmat.2014.03.028

5. N.-W. Choi, I. Mori, and Y. Ohama, Waste Management, 26(2), 189(2006), https://doi.org/10.1016/j.wasman.2005.05.008

6. M. Amianti, and V. R. Botaro, Cement and Concrete Composites, 30(1), 23(2008), https://doi.org/10.1016/j.cemconcomp.2007.05.014

7. A. Bandyopadhyay, and G. C. Basak, Materials Science and Technology, 23(3), 307(2007), https://doi.org/10.1179/174328407X158640

8. M. E. Ojewumi, O. E. Kolawole, D. Oyekunle, O. S. Taiwo, and A. Adeyemi, Journal of Ecological Engineering, 20(4),35(2019), https://doi.org/10.12911/22998993/102614

9. M. E. Ojewumi, I. J. Akwayo, O. S. Taiwo, O. M. Obanla, A. A. Ayoola, E. O. Ojewumi, and E. A. Oyeniyi, International Journal of Pharmaceutical and Phytopharmacological Research, 8(3), 46(2018).

10. M. E. Ojewumi, P.C. Ogele, D.T. Oyekunle, J.A. Omoleye, S. O. Taiwo, and Y.D. Obafemi, In Proceedings of 3rd International Conference on Science and Sustainable Development, IOP Conference Series: Journal of Physics, 1299,012011(2019), https://doi.org/10.1088/1742-6596/1299/1/012011

11. J. Van Wyk, and M. Mohulatsi, Bioresource Technology, 86(1), 21(2003).

12. W. G. Willats, J. P. Knox, and J. D. Mikkelsen, Trends in Food Science \& Technology, 17(3), 97(2006), https://doi.org/10.1016/j.tifs.2005.10.008

13. M. R. Wilkins, L. Suryawati, N. O. Maness, and D. Chrz, World Journal of Microbiology and Biotechnology, 23(8), 1161(2007), https://doi.org/10.1007/s11274-007-9346-2

14. K. Wani, and R. Rao, Saudi Journal of Biological Sciences, 20(2), 149(2013), https://doi.org/10.1016/j.sjbs.2013.01.001

15. P. Varotkar, P. Tumane, and D. D. Wasnik, International Journal of Pure Appl ied Bioscience, 4, 206(2016), https://doi.org/10.18782/2320-7051.2329

16. G. Tripathi, and P. Bhardwaj, Bioresource Technology, 92(2), 215(2004), https://doi.org/10.1016/j.biortech.2003.08.013

17. M.E. Ojewumi, M.E. Emetere, C.V. Amaefule, B.M. Durodola, and O. D. Adeniyi, International Journal of Pharmaceutical Sciences and Research, 10(3), 1246(2018), https://doi.org/10.13040/IJPSR.0975-8232

18. M.E. Ojewumi, D.T. Oyekunle, C.V. Amaefule, J.A. Omoleye, and A.T. Ogunbiyi, In Proceedings of International Conference on Engineering for Sustainable World, Journal of Physics: Conference Series, 1378, 022066 (2019), https://doi.org/10.1088/1742-6596/1378/2/022066

19. D. Ratkowsky, J. Olley, T. McMeekin, and A. Ball, Journal of Bacteriology, 149(1), 1(1982), https://doi.org/0021-9193/82/10001-05\$02.00/0

20. V. Dattoma, S. Giancane, R. Nobile, and F. Panella, International Journal of Fatigue, 28(2), 89(2006), https://doi.org/10.1016/j.ijfatigue.2005.05.001

21. D. J. Dunn, Engineering and Structural Adhesives: iSmithers Rapra Publishing, (2004).

22. O. Udensi, E. V. Ikpeme, E. A. Uyoh, and E. A. Brisibe, Nigerian Journal of Biotechnology, 20(1), 28(2009).

23. A. J. Gunorubon, Research Journal in Engineering and Applied Sciences, 1(4), 219(2012).

24. C. Shin, Journal of Colloid and Interface Science, 302(1), 267(2006), https://doi.org/10.1016/j.jcis.2006.05.058 
RASĀYAN J. Chem.

Vol. 14 | No. 3 |1835-1844| July - September | 2021

25. M. E. Ojewumi, O. A. Adeeyo, O. M. Akingbade, D. E. Babatunde, A. A. Ayoola, O. O. Awolu, E. O. Ojewumi, and O. J. Omodara, International Journal of Pharmaceutical Sciences and Research, 9(8), 1000(2018), https://doi.org/10.13040/IJPSR.0975-8232

26. M.E. Ojewumi, G.O. Kayode, J.A. Omoleye, and D.T. Oyekunle, International Journal of Civil Engineering and Technology, 10(1), 623(2019).

27. M. E. Ojewumi, K. G. Oyeyemi, M. E. Emetere, and J. O. Okeniyi, Data in Brief, 19, 2163(2018), https://doi.org/10.1016/j.dib.2018.06.112

28. M.E. Ojewumi, J.A. Omoleye, A.A. Adesola. International Journal of Applied Engineering Research, 12(22), 12852(2017).

29. M.E. Ojewumi, J.A. Omoleye, Journal of Nutritional Health \& Food Engineering, 8(1), 1(2018).

30. M.E. Ojewumi, E.V. Anenih, O.S.Taiwo, B.T. Adekeye,O.O. Awolu,E.O. Ojewumi, Journal of Ecological Engineering, 19(2), 226(2018), https://doi.org/10.12911/22998993/83564

31. M.E. Ojewumi, J.A. Omoleye, A.A. Ayoola, B.T. Adekeye, International Journal of Food Science and Nutrition, 3(1), 117(2018).

32. M.E. Ojewumi, A.O. Odubiyi, and J. Omoleye, Novel Techniques in C Nutrition and Food Science, 2(4), 1(2018).

33. M.E. Ojewumi, Ph.D. Thesis, Department of Chemical Engineering Covenant University, Ota, Ogun State, Nigeria (2016).

34. M.E. Ojewumi, D.T. Oyekunle, G.P Ekanem, O.R. Obanla, O.M. Owolabi, In Proceedings of International Conference on Engineering for Sustainable World. Journal of Physics: Conference Series, 1378, 042019(2019), https://doi.org/10.1088/1742-6596/1378/4/042019

35. M.E. Ojewumi, J.A. Omoleye, A.A. Ajayi, International Journal of Engineering Research \& Technology, 5(4), 249(2016).

36. T. Guma, C. Allison, Experimental Stress Analysis of Some Adhesively Bonded Joints.

37. M.Yang and K. Rosentrater, 2015 ASABE Annual International Meeting. American Society of Agricultural and Biological Engineers (2015), https://doi.org/10.13031/aim.20152184612

[RJC-6226/2020] 